\title{
Pathogeographic Studies of Sugarcane Downy Mildew in TAIWAN II. A Preliminary Characterization of Host Factors in Four Pathogeographic Regions*
}

\author{
E. S. PoON**, L.S. LEU ${ }^{* * *}$ and C. LIU**** \\ 潘 崇儀**.呂 理榮***・劉 清**** : 台湾に括けるサトウキビベと病の病害地理的研究 \\ II .4 地域でのべと病発生に対する寄主の役割*
}

\begin{abstract}
The disease and host attributes of four different pathogeographic regions from 1965-1978 were compared. The regions studied were Taichung (nonepidemic region), Huwey (sporadic region), Hsinying (region of main damage) and Pingtung (region of marginal damage). The disease attributes studied were disease intensity, extensity, frequency and duration. The host attributes were planting acreage of sugarcane and corn, the ratio of the two; ratio of disease-conducive varieties planted and disease potential index of the sugarcane population; the ratio of susceptible and resistant corn varieties and the practice of corn interplanting. Good correlation was found with the ratio of disease-conducive sugarcane variety, the disease potential index of the sugarcane population and disease incidence on sugarcane. Failure to find correlation with disease on sugarcane and the corn host population is probably due to the inadequacy of the historical data of corn. The host factors accounting for the different levels of disease intensities in the different pathogeographic regions were also discussed.
\end{abstract}

(Received July 22, 1981)

Key Words : pathogeography, Sclerospora sacchari, host factor, Taiwan.

\section{Introduction}

Host is a major component of the disease pyramid in plant disease epidemiology. The kind of host tissue available is a determining factor of disease intensity. Therefore ecological survey of host population and the occurrence of alternative hosts and reservoirs are usually conducted in the characterization of pathogeographic regions. An example is offered by the study on vegetation pattern of cadang-cadang disease of coconut palm to elucidate if some weeds may serve as inoculum reservoir of the pathogen ${ }^{12)}$. It has

* This work was supported in part by the National Science Council funds for research and development in science administration for 1980 and 1981.

** The senior author was affiliated with National Science Council, ROC during the course of this study. Present address : Resource Systems Institute, East-West Center, Honolulu, Hawaii, USA

*** Plant Protection Center, Taiwan, Wufeng, Taiwan, ROC

**** Department of Agronomy, Taiwan Agricultural Research Institute, Taichung. Taiwan, ROC 
been reported that sugarcane, corn and teosinte are hosts of the sugarcane downy mildew pathogen, however, teosinte is not cultivated in Taiwan ${ }^{9}$. Therefore only corn and sugarcane will be considered as the hosts here. Epidemics of sugarcane downy mildew has been attributed to increasing corn planting acreage ${ }^{6)}$. However, detailed analysis of the corn population is not feasible because assess to data on corn varieties is difficult. Only two major varieties are studied, since it has been reported that Tainan 5 was highly susceptible ${ }^{5)}$ and Tainan 11 was resistant ${ }^{4)}$, and both varieties were believed to have great impact on the sugarcane downy mildew disease dynamics. The highly susceptible white corn varieties ${ }^{2)}$ which were planted in large acreage were not studied because they were usually planted in dispersed patches instead of concentrated in large stretches as in the planting of Tainan 5 or Tainan 11. As data on sugarcane varieties are readily available, it is therefore possible to conduct a reliable classification of varieties into two distinct populations, resistant and susceptible. An interesting report on oat crown rust illustrates that in nature a specific resistance gene frequency of only about $39 \%$ can be considered adequate protection against the most virulent and prevalent group of strains of the pathogen, field experience with multilines resistant and susceptible to rust also indicates that having one-third of the plants resistant was adequate to protect the host population ${ }^{1)}$. Although the type of resistance exhibited in sugarcane and the presence of races or biotypes in the downy mildew pathogen has not been studied, it is likely that the proportion of resistant and susceptible plants in the population may also have important bearing on disease epidemics. This paper focused on the effect of host environment composed of sugarcane and corn plantings on downy mildew disease. Some selected host attributes in the four pathogeographic regions, Taichung, Huwey, Hsinying and Pingtung were compared and their relations to disease were also studied. Other host characteristics such as host nutrition and fertilizer application, growth stage of the hosts which have been reported to significantly affect downy mildew disease incidence ${ }^{3,7,8,11)}$ were not studied because the historical data do not provide precise information on these aspects.

\section{Materials and Methods}

Data on the number of diseased farms, disease and planting acreage of sugarcane for the sugar factory districts from 1965 to 1978 were obtained from the Division of Agricultural Technology, Taiwan Sugar Corporation. Only data of Taiwan Sugar Corporation farms were used, as contract farms were not considered because of the great fluctuation of sugarcane planting on those farms from year to year. Data on planting acreage of corn and hybrid varieties were obtained from the Food Bureau and Seed Propagation Station, respectively. (The planting acreage is obtained by converting the number of kilograms of seeds sold into hectares; $25 \mathrm{~kg}$ of seeds for $1 \mathrm{ha}$ ). Data of only four regions, Taichung, Huwey, Hsinying and Pingtung were compiled. Cumulative annual means for 14 years were computed for the disease attributes (intensity, extensity, frequency and duration) and the host attributes (sugarcane planting acreage, ratio of disease-conducive varieties planted, disease potential index; corn planting acreage and ratio of Tainan 5 and Tainan 11 planted). All varieties reported to be infected in the regions in the period studied were considered disease-conducive varieties. They may 
differ from region to region*. For Taichung where no infection was reported, infected varieties reported in any one of the sugar factory districts were considered as diseaseconducive varieties in Taichung. Disease potential index is the product of ratio planted and disease index of the variety. Disease index is in turn obtained by dividing cumulative infection ratio of the variety in the region for 14 years with cumulative ratio of the variety planted in the region. The disease index for the disease-conducive varieties in Taichung

Table 1. Regional comparison of disease and host attributes ${ }^{a)}$

\begin{tabular}{|c|c|c|c|c|}
\hline $\begin{array}{l}\text { Disease and host } \\
\text { attributes }\end{array}$ & Taichung & Huwey & Hsinying & Pintung \\
\hline $\begin{array}{l}\text { Regional pathogeographic } \\
\text { classification }\end{array}$ & nonepidemic & sporadic & main damage & marginal damage \\
\hline \multicolumn{5}{|l|}{ DISEASE } \\
\hline Intensity ${ }^{b)}$ & 0 & 0.99 & 6.56 & 1.48 \\
\hline Extensity ${ }^{()}$ & 0 & 0.12 & 0.59 & 0.15 \\
\hline Frequency ${ }^{\mathrm{d}}$ ) & 0 & 3.25 & 8.33 & 3.46 \\
\hline \multicolumn{5}{|l|}{ Duration } \\
\hline e) & 0 & 6 & 2 & 3 \\
\hline f) & 0 & 3 & 3 & 3 \\
\hline в) & 0 & 1 & 1 & 1 \\
\hline h) & 0 & 3 & 1 & 1 \\
\hline i) & 0 & 6 & 9 & 10 \\
\hline \multicolumn{5}{|l|}{ HOST } \\
\hline \multicolumn{5}{|l|}{ Sugarcane } \\
\hline Planting acreage (ha) & 1357.97 & 2022.82 & 520.63 & 4013.13 \\
\hline $\begin{array}{l}\text { Percentage of disease-conducive } \\
\text { varieties }^{j \text { j }}\end{array}$ & 67.85 & 47.93 & 78.30 & 79.93 \\
\hline Disease potential Index ${ }^{k}$ & 67.85 & 94.77 & 88.49 & 95.43 \\
\hline \multicolumn{5}{|l|}{ Corn } \\
\hline Planting acreage (ha) & 1216.31 & 1696.38 & 609.04 & 490.10 \\
\hline Percentage of Tainan 5 planted & 19.077 & 39.99 & 27.28 & 2.19 \\
\hline Percentage of Tainan 11 planted & 1.69 & 11.66 & 69.31 & 2.37 \\
\hline Corn interplanting ${ }^{1)}$ & 0 & 0 & 1 & 0 \\
\hline $\begin{array}{l}\text { Ratio of sugarcane and corn } \\
\text { planting acreage }\end{array}$ & 1.11 & 1.19 & 0.85 & 8.18 \\
\hline SOIL & $\begin{array}{l}\text { red soil, } \\
\text { red yellow } \\
\text { podzolic soil }\end{array}$ & $\begin{array}{l}\text { slate, sandstone } \\
\& \text { shale alluvial } \\
\text { soil }\end{array}$ & $\begin{array}{l}\text { low humic } \\
\text { grey soil }\end{array}$ & $\begin{array}{l}\text { slate, sandstone } \\
\& \text { shale alluvial } \\
\text { soil }\end{array}$ \\
\hline
\end{tabular}

a) cumlative annual means from 1965-1978, b) infection ratio, c) of diseased farms/ of farms in the region, d) $\#$ of diseased farms reported during the period studied/ $\#$ of farms in the region $\times$ of years studied, e) of alternations of diseased and nondiseased period (years), g) first appearance of first epidemics (Two epidemics occurred during the period studied, the first in 1965, the second in 1973, e. g. when disease occurs in the region in 1965 or 1973, it is given a value of 1 , if it appears in 1966 or 1974, it is given a value of 2), h) first appearance of second epidemics, i) longest diseased period (years), j) sum of disease acreage of all varieties/ total planting acreage $\times 100 \%$, for Taichung, varieties that have been reported to be infected in any one of the sugar factory districts ware considered as disease-conducive varieties in Taichung, $\mathrm{k}$ ) sum of all varieties (ratio of variety $\times$ disease index), disease index (cumulative infection ratio/ cumulative \% of the variety planted), 1) region with corn interplanting is given a value of 1 , that with no corn interplanting is given a value of 0 .

* Hsinying: F155, F161, F160, F167, 58-2382, F146.

Huwey: F146, F153, F151, F156, NCo310, F157, F164, F155.

Pingtung: F154, F155, F146, F148, F156, F160, F162, F164, F167, F157. 
is obtained by dividing the cumulative ratio of the varieties planted for all the regions. The ratio and indices computed for Taichung are speculative and overestimated, it should be considered as a rough reference for comparison only.

\section{Results}

Regional comparison of disease and host attributes of the different pathogeographic regions (Table 1) indicates that disease intensity, and disease duration in terms of the number of alternations of diseased and nondiseased periods and the longest diseased period are attributes distinguishing the different pathogeographic regions. Disease extensity and disease frequency are not as good for discerning the pathogeographic classification. The host factors that discriminate the different regions are: the sugarcane planting acreage, ratio of disease-conducive varieties planted, disease potential index, the ratio of sugarcane and corn planting acreage and the practice of corn interplanting. The soil conditions of Hsinying and Taichung are quite different, but that of Huwey and Pingtung are similar. Good correlation was found with disease intensity (infection ratio) and the ratio of disease-conducive sugarcane varieties, and disease potential index in Huwey, Hsinying and Pingtung. The two factors account for $42-74 \%$ of variation in disease intensity in the different regions. Negative correlation was found with disease and sugarcane planting acreage in Huwey probably because the decrease in disease corresponds with increased planting of resistant varieties. Although good correlation was found with Tainan 5 planting acreage and disease intensity in Pingtung, the proportion of corn planted as compared to that of sugarcane is small, thus making the correlation not very meaningful. Good correlation was found with the ratio of sugarcane and corn planting acreage and disease (Table 2).

The dynamics of ratio of disease-conducive varieties and disease potential index of the different pathogeographic regions (Fig. 1) conform with the pathogeographic classification. The ratio of disease-conducive varieties planted was distinctly lower in Taichung and the disease potential index and ratio of the disease-conducive varieties

Table 2. Correlation coefficients of disease intensity and some host attributes in different pathogeographic regions from 1965-1978

\begin{tabular}{lcll}
\hline \hline Host attribute & Huwey & Hsinying & \multicolumn{1}{c}{ Pingtung } \\
\hline Sugarcane $^{\mathrm{a})}$ & & & \\
Planting acreage & $-0.896(80)^{* * *}$ & 0.209 & 0.489 \\
Percentage of disease-conducive varieties & $0.663(44)^{* *}$ & $0.800(64)^{* * *}$ & $0.684(47)^{* *}$ \\
Disease potential index & $0.647(42)^{* *}$ & $0.858(74)^{* * *}$ & $0.815(66)^{* * *}$ \\
Corn & & & \\
Planting acreage & -0.428 & -0.356 & -0.437 \\
Tainan 5 planting acreage & & & \\
Tainan 11 planting acreage & 0.220 & -0.062 & $0.800(64)^{* * *}$ \\
Tainan 5/Tainan 11 & -0.192 & -0.163 & 0.149 \\
Sugarcan planting acreage/corn planting & -0.174 & 0.329 & -0.128 \\
acreage $^{\mathrm{a})}$ & -0.150 & $0.546(30)^{*}$ & $0.523(27)^{*}$ \\
\hline
\end{tabular}

*** significant at 0.001 level, ** significant at 0.01 level, * significant at 0.05 level

a) numbers in parenthesis indicate the percentage of variation accounted for by the factor in the region. 


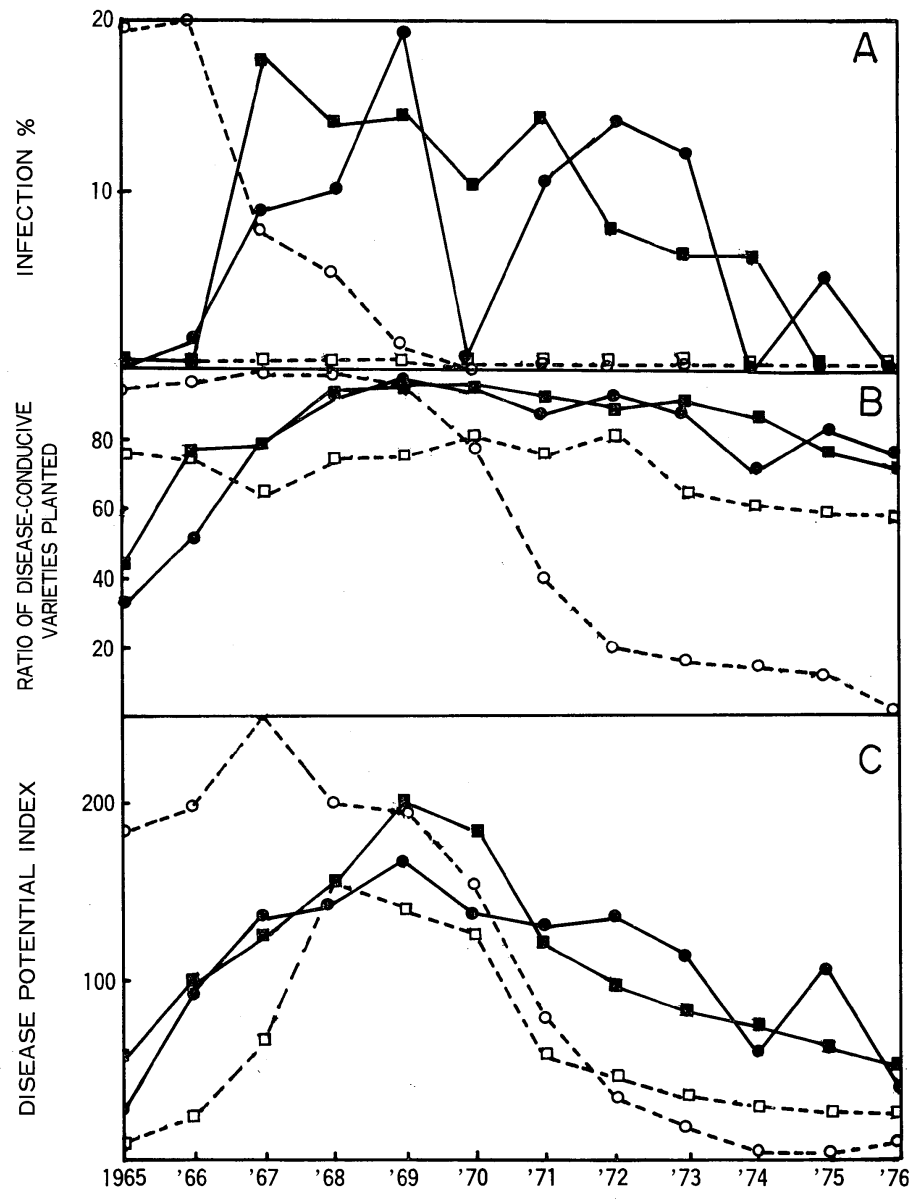

Fig. 1. Comparison of infection percentage, ratio of disease conducive varieties planted and disease potential index of four pathogeographic regions from 1965-1976.

- Pingtung, Hsinying, $\bigcirc$ Huwey and $\square$ Taichung

planted in Huwey distinctly dropped after 1970, this parallels the disease pattern. Although disease in Hsinying was more severe than Pingtung, the level of disease potential index in Pingtung was higher than that of Hsinying, this can probably be accounted for by the practice of corn interplanting, the larger population of corn and smaller population of sugarcane in Hsinying.

\section{Discussion}

Disease intensity, extensity, frequency and the longest diseased period have been found to be well correlated in another paper ${ }^{10)}$. The above results indicate that disease intensity, longest diseased period and number of alternations of diseased and nondiseased periods correspond with the regional pathogeographic classification, while disease extensity 
and frequency do not correspond as well, and the other disease duration attributes do not correspond at all. It is suggested that disease intensity and the longest disease period may be the best disease attributes for regional characterization.

In general there is no close correspondence of the corn host attributes and the pathogeographic classification. The total corn planting acreage and the planting acreage of Tainan 5 and Tainan 11 do not correspond to the pathogeographic classification at all. Since the original data on corn were categorized according to villages and towns, but reclassified into sugar factory districts in this study, authenticity of the data may be lost during the conversion. Also it should be noted that the seeds sold in one region may not be planted in the same region. For instance, many of the Tainan 5 seed sold in Taichung are actually planted in the Tainan area (personal communication, S. C. Chang). This further enhances the difficulty in finding the association between corn planting and sugarcane downy mildew disease. Furthermore, local varieties are planted and ricecorn relay interplanting is practiced in Taichung, creating an agroecosystem distinct from the sugarcane-corn relay interplanting or single crop system in Huwey, Hsinying and Pingtung. Failure to find the relationship between corn planting and sugarcane downy mildew due to improper and unreliable data does not mean that such relationship does not exist. The sugarcane planting acreage, the ratio of sugarcane and corn planting acreage, and the corn interplanting practice appear to be useful attributes for regional characterization. It is logical that disease intensity should be associated with the size of host population in the region. Corn is generally believed to provide inoculum source more readily than sugarcane, therefore it is possible that a low ratio of sugarcane to corn planting acreage is more favorable for disease development in the region. This is exemplified in the low ratio in the main damage region of Hsinying and the high ratio in the marginal damage area of Pingtung. Likewise, corn interplanting provides an efficient inoculum propagation and dispersal system which easily explains the high disease intensity in Hsinying. Percent of disease-conducive varieties and disease potential index appear to be crucial attributes for regional characterization because the determining factor of sugarcane downy mildew disease epidemics appear to be the susceptibility and the resistance of the variety and the ratio of the total host population which the variety consitutes. Interestingly, disease incidences appear insignificant when resistant varieties constitute over $20 \%$ of the sugarcane population as opposed to the $30 \%$ reported for the oat crown rust system ${ }^{1)}$. This is illustrated in the disease-free region of Taichung and the nonepidemic years in Huwey, Hsinying and Pingtung.

To summarize, the high disease intensity in Hsinying district was probably due to corn interplanting and the relatively large proportion of corn planted. Disease was also more intense due to the small planting acreage of sugarcane since high infection level can be attained more easily in a small population. Although the enviromental conditions in Huwey and Hsinying are similar, topographic or soil conditions differ. In Huwey, disease occurred only at the early part of the period studied because the ratio of resistant varieties increased after 1970; and disease intensity was lower than that at Hsinying. Disease was more severe in Pingtung when compared to Huwey but less than in Hsinying. This is probably due to the vast sugarcane planting acreage and the limited corn planting acreage. The disease free region of Taichung can probably be explained by the lower disease potential index and lower ratio of the disease-conducive varieties. 
The authors wish to thank Dr. W. H. Hsieh, Sugar Research Institute, for his generous assistance in the course of this study, and Mr. S. C. Chang for his advice during the preparation of this manuscript. Thanks are also due to the Division of Agricultural Technology, Taiwan Sugar Corporation for providing data on sugar cane, the Food Bureau for providing data on corn planting acreage and Seed Propagation Station for providing data on planting acreage of Tainan 5 and Tainan 11.

\title{
Literature cited
}

1. Browning, J. A., Frey, K. J., McDaniel, M. E., Simons, M. D. and Wahl, I. (1979). Indian J. Genet. \& Plant Breed. 39 (1) : 3-9.

2. Chang, S. C., Chen, N. C. and Sun, M. H. (1965). Rep. Corn Res. Center 1: 35-43 (In Chinese).

3. Chang, S. C. and Wu, T.H. (1970). Ibid. 8: 11-16 (In Chinese).

4. Chang, S. C. and Wu, Y.Z. (1972). Ibid. 9: 1-5 (In Chinese).

5. Chang, S. C. and Yen, J. I. (1965). Ibid. 3: 33-35 (In Chinese).

6. Chu, H. T. (1967). Taiwan Sugar 14 (2): 10-13.

7. Leu, L. S. (1962). Taiwan Sugar Expt. Sta. Res. Rep. 26:17-28 (In Chinese).

8. Leu, L. S. and Chu, T. L. (1959). Proc. Int. Soc. Sugarcane Tech. 10: 1129-1133.

9. Miyake, T. (1912). Sugarcane downy mildew survey report. Taiwan Sugar Industry Special Report 1, 61 pp.

10. Poon, E. S., Leu, L. S., Liu, C. and Cheng, W. T. (1981). Ann. Phytopath. Soc. Japan 48: 153-161.

11. Sing, R. S., Chaube, H. S., Singh, N., Asnani, V. L. and Singh, R. (1970). Indian Phytopath. 23 : 209-215.

12. Zelazny, L. (1980). Phytopathology 70: 700-703.

\section{和 文 摘 要}

\section{台湾に括けるサトウキビベと病の病害地理的研究 \\ II . 4 地域のベと病発生に対する寄主の役割}

\author{
潘 崇義・呂 理榮・劉 清
}

4 病害地理区域, すなわち台中 (非流行地区), 虎尾 (偶発地区), 新営 (主要被害地区) および攵東 (周 辺被害地区）に和汀るべと病の発生と宿主の分布との関係を 1965～1978年の資料を用いて比較した。病害発 生に関する諸因子の中で分析したのは発病強度, 発病範囲, 頻度执よび持続性で, 寄主に関してはサトウキ ビ执よびトウモロコシの栽培面積とその比率，サトウキビの感受性品種の栽培面積比率抢よびサトウキビ群 落の発病可能指数, 感染性および抵抗性トウモロコシの栽培比率ならびにトウモロコシの間作である。その らちで感受性品種の栽培面積とサトウキビ群落中の発病可能指数との間には密接な関係がみられた。サトウ キビの発病とトウモロコシの栽培面積の間に関係がみられなかったのはトウモロコシの栽培資料の不完全な ことに帰せられるものと考えられる。それぞれの病害地理区域の発病程度に関係する寄主要因についても検 討した。 